\title{
THE ELECTROCARDIOGRAM IN THE NORMAL INFANT
}

\author{
BY \\ OLIVE SCOTT AND DORIS FRANKLIN \\ From The Heart Clinic, Royal Liverpool Children's Hospital, and the Department of Child Health, \\ University of Liverpool \\ Received November 8, 1962
}

There are several studies of electrocardiograms in children (Ziegler, 1951; Gros, Gordon, and Miller, 1951; Bengtsson, 1956; Sodi-Pallares et al., 1958), but the numbers of children under 1 year of age in these series are small. In Ziegler's monograph (1951), the numbers vary from 22 to 41 in different age-groups during the first year of life. Gros et al. (1951) include electrocardiograms from only nine infants in the age-group 1 week to 3 months and only six in the age-group 6 months to 1 year. The analysis of Bengtsson (1956) deals only with the terminal complex of the cardiogram and includes only nine children under 1 month of age; nine between 1 and 2 months; 15 between 3 and 5 months; and 22 between 6 and 11 months. Sodi-Pallares et al. (1958) do not specify the number of infants.

There have been few studies of the electrocardiograms of infants during the first week of life, and in only one series (Datey and Bharucha, 1960) have records been taken daily from the same 44 infants. Michaëlsson (1959) obtained records from 37 infants on the first, second, third, fifth, and seventh days of life. Richman and Master (1951) obtained daily records for the first four days of life but the number of infants is not stated.

We have seen 600 infants with congenital heart disease in this clinic. In some of these infants where right ventricular hypertrophy was diagnosed on other grounds, the measurements of the $R$ waves in the præcordial leads V3R and V1 of the electrocardiogram were below the normal values given in published reports.

\section{SubJECTS AND METHODS}

It was therefore decided to carry out a study of the electrocardiogram in normal infants. Records were taken from the same 50 infants ( 29 girls and 21 boys) at 5 days, 1 month, 3 months, and 6 months: only 42 of these 50 infants attended for records at 1 year of age. In addition daily records for the first seven days of life were taken from 20 of these 50 infants. Q, R, and $\mathbf{S}$ waves were measured in all these records. The $T$ waves were measured in 17 of the daily records, in 40 infants at 5 days, 1 month, 3 months, and 6 months, and in 25 infants at 1 year.

The infants in this series were a random selection of normal babies born at Mill Road Maternity Hospital between August 1956 and April 1958. Most were from families of the lower income groups (3, 4, and 5 of the Registrar General's social classification). There were no abnormal signs in the cardiovascular system in any of these babies and chest radiographs taken at 5 days, 3 months, and 1 year were all normal.

The electrocardiograms were recorded with the direct writer Cambridge 'Electrite' recorder, the infants being supine and unsedated. Leads I, II, III, AVR, AVL, and AVF were recorded in direct sequence using infant electrodes measuring $45 \mathrm{~mm} . \times 20 \mathrm{~mm}$. The præcordial leads V1, V3, V6, and V3R were taken at sites recommended by the British Cardiac Society (1949) using a Burger suction type electrode $1.25 \mathrm{~cm}$. in diameter. At least six complexes were taken in all leads; the paper speed was $25 \mathrm{~mm}$. per second and the sensitivity was $1 \mathrm{mV}$ to $1 \mathrm{~cm}$. Q, R, S, and T waves were measured in all leads to an accuracy of $0.5 \mathrm{~mm}$., and tables of mean, maximal, and minimal values for each wave were prepared. Histograms 
TABLE I

Q WAVES

\begin{tabular}{|c|c|c|c|c|c|c|c|c|c|c|c|c|c|}
\hline \multirow[b]{2}{*}{$\underset{\text { (mth.) }}{\text { Age }}$} & \multirow[b]{2}{*}{$\begin{array}{c}\text { Number } \\
\text { of } \\
\text { subjects }\end{array}$} & \multicolumn{3}{|c|}{ I } & \multicolumn{3}{|c|}{ II } & \multicolumn{3}{|c|}{ III } & \multicolumn{3}{|c|}{ AVR } \\
\hline & & mean & $\max$ & $\min$. & mean & $\max$ & min. & mean & $\max$ & $\min$. & mean & $\max$. & $\min$. \\
\hline $\begin{array}{l}1 \text { day } \\
5 \text { days } \\
1 \\
3 \\
6 \\
12\end{array}$ & $\begin{array}{l}20 \\
50 \\
50 \\
50 \\
50 \\
42\end{array}$ & $\begin{array}{l}0 \\
0 \\
0 \cdot 1 \\
0 \cdot 1 \\
0 \cdot 1 \\
0 \cdot 3\end{array}$ & $\begin{array}{l}0 \\
0 \cdot 5 \\
1 \\
2 \\
3 \\
3\end{array}$ & $\begin{array}{l}0 \\
0 \\
0 \\
0 \\
0 \\
0\end{array}$ & $\begin{array}{l}0.6 \\
0.9 \\
0.9 \\
1.7 \\
1.8 \\
1.3\end{array}$ & $\begin{array}{l}2 \\
3 \cdot 5 \\
3 \\
6 \\
6 \\
4\end{array}$ & $\begin{array}{l}0 \\
0 \\
0 \\
0 \\
0 \\
0\end{array}$ & $\begin{array}{l}1.4 \\
1.6 \\
1.4 \\
2.9 \\
3 \cdot 4 \\
3.2\end{array}$ & $\begin{array}{c}4 \\
6 \\
4 \\
10 \\
8 \cdot 5 \\
10 \cdot 5\end{array}$ & $\begin{array}{l}0 \\
0 \\
0 \\
0 \\
0 \\
0\end{array}$ & $\begin{array}{l}0.6 \\
0.8 \\
0.5 \\
0.7 \\
0.8 \\
0.8\end{array}$ & $\begin{array}{l}1 \cdot 5 \\
6 \\
4 \\
8 \cdot 5 \\
9 \\
10 \cdot 5\end{array}$ & $\begin{array}{l}0 \\
0 \\
0 \\
0 \\
0 \\
0\end{array}$ \\
\hline
\end{tabular}

TABLE II

R WAVES

\begin{tabular}{|c|c|c|c|c|c|c|c|c|c|c|c|c|c|}
\hline \multirow[b]{2}{*}{$\begin{array}{c}\text { Age } \\
\text { (mth.) }\end{array}$} & \multirow[b]{2}{*}{$\begin{array}{c}\text { Number } \\
\text { of } \\
\text { subjects }\end{array}$} & \multicolumn{3}{|c|}{ I } & \multicolumn{3}{|c|}{ II } & \multicolumn{3}{|c|}{ III } & \multicolumn{3}{|c|}{ AVR } \\
\hline & & mean & $\max$ & $\min$. & mean & $\max$ & $\min$. & mean & $\max$ & $\min$. & mean & $\max$. & min. \\
\hline 1 day & 20 & $1 \cdot 3$ & $4 \cdot 5$ & 0 & $4 \cdot 1$ & 15 & 0 & $8 \cdot 3$ & 16 & 2 & $3 \cdot 8$ & 12 & 0 \\
\hline 5 days & 50 & 1.5 & 6 & 0 & $4 \cdot 6$ & 13 & 0.5 & 5.9 & 15 & 1 & $3 \cdot 1$ & 8 & 0 \\
\hline & 50 & $2 \cdot 5$ & 7 & 0 & $7 \cdot 5$ & 15 & 2 & $7 \cdot 8$ & 15 & 2 & $2 \cdot 8$ & 8 & 0 \\
\hline 3 & 50 & $6 \cdot 1$ & 12 & 1 & $11 \cdot 6$ & 22 & $4 \cdot 5$ & $9 \cdot 8$ & 21 & 2 & $2 \cdot 7$ & $6 \cdot 5$ & 0 \\
\hline 6 & 50 & $6 \cdot 5$ & 13 & 0 & $10 \cdot 7$ & 21 & $3 \cdot 5$ & $8 \cdot 8$ & $17 \cdot 5$ & 0.5 & $2 \cdot 4$ & $6 \cdot 5$ & 0 \\
\hline 12 & 42 & $7 \cdot 8$ & 14 & 0 & 12.0 & 17 & $4 \cdot 5$ & $8 \cdot 6$ & 17.5 & 1 & $2 \cdot 5$ & $7 \cdot 5$ & 0 \\
\hline
\end{tabular}

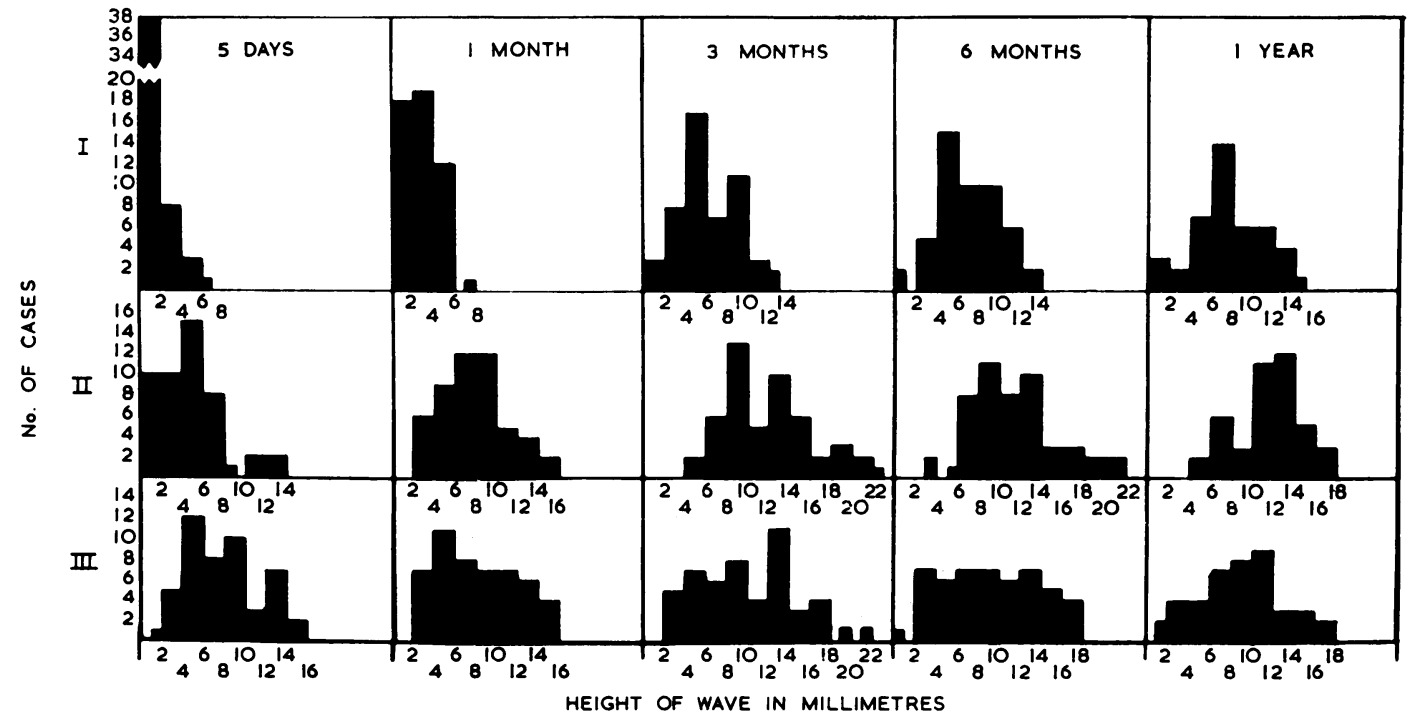

Fig. 1.-Distribution of $\mathbf{R}$ wave values in leads I, II, III 
TABLE I (continued)

\begin{tabular}{|c|c|c|c|c|c|c|c|c|c|c|c|c|c|c|c|c|c|}
\hline \multicolumn{3}{|c|}{ AVL } & \multicolumn{3}{|c|}{ AVF } & \multicolumn{3}{|c|}{ V3R } & \multicolumn{3}{|c|}{ V1 } & \multicolumn{3}{|c|}{ V3 } & \multicolumn{3}{|c|}{ V6 } \\
\hline mean & $\max$. & $\min$. & mean & $\max$ & $\min$. & mean & $\max$ & $\min$. & mean & $\max$ & $\min$. & mean & $\max$ & $\min$. & mean & $\max$. & $\min$. \\
\hline 0.1 & 2 & 0 & 1.0 & 2 & 0 & 0 & 0 & 0 & 0 & 0 & 0 & 0 & 0 & 0 & 0.2 & 1 & 0 \\
\hline $0 \cdot 1$ & $2 \cdot 5$ & 0 & 1.4 & 4 & 0 & 0 & 0 & 0 & 0 & 0 & 0 & 0 & 0 & 0 & 0 & 3 & 0 \\
\hline 0.2 & 4 & 0 & 1.3 & 3 & 0 & 0 & 0 & 0 & 0 & 0.5 & 0 & 0 & 0 & 0 & 0.5 & 3 & 0 \\
\hline $0 \cdot \overline{1}$ & $3 \cdot 5$ & 0 & 2.6 & 7 & 0 & 0 & 0.5 & 0 & 0 & 1 & 0 & 0 & 0 & 0 & 0.9 & 3 & 0 \\
\hline 0.1 & 2 & 0 & $2 \cdot 7$ & $7 \cdot 5$ & 0 & 0 & 0.5 & 0 & 0 & 0.5 & 0 & 0 & 0 & 0 & 1.0 & 5 & 0 \\
\hline $0 \cdot \hat{1}$ & 2 & 0 & $2 \cdot 4$ & 7 & 0 & 0 & 0.5 & 0 & 0 & 0.5 & 0 & 0 & 0 & 0 & $1 \cdot 1$ & 4 & 0 \\
\hline
\end{tabular}

TABLE II (continued)

\begin{tabular}{|c|c|c|c|c|c|c|c|c|c|c|c|c|c|c|c|c|c|}
\hline \multicolumn{3}{|c|}{ AVL } & \multicolumn{3}{|c|}{ AVF } & \multicolumn{3}{|c|}{ V3R } & \multicolumn{3}{|c|}{ V1 } & \multicolumn{3}{|c|}{ V3 } & \multicolumn{3}{|c|}{ V6 } \\
\hline mean & $\max$. & min. & mean & $\max$ & $\min$. & mean & $\max$ & min. & mean & max. & min. & mean & $\max$ & $\min$. & mean & max. & min. \\
\hline $\begin{array}{l}1.5 \\
1.6 \\
1.9 \\
3.9 \\
4 \cdot 3 \\
5 \cdot 1\end{array}$ & $\begin{array}{c}4 \\
9 \cdot 5 \\
5 \cdot 5 \\
10 \\
13 \\
13.5\end{array}$ & $\begin{array}{l}0 \\
0 \\
0 \\
0 \\
0 \\
1\end{array}$ & $\begin{array}{r}6.8 \\
6.0 \\
7.9 \\
11.3 \\
9.0 \\
9.2\end{array}$ & $\begin{array}{l}16 \cdot 5 \\
13 \\
14 \\
20 \\
18 \cdot 5 \\
17\end{array}$ & $\begin{array}{l}1 \\
0.5 \\
1.5 \\
0 \\
0 \\
1\end{array}$ & $\begin{array}{l}8.5 \\
6.5 \\
5.4 \\
6 \cdot 7 \\
6.9 \\
6.2\end{array}$ & $\begin{array}{l}17 \\
14 \\
12 \\
15 \cdot 5 \\
13 \\
15\end{array}$ & \begin{tabular}{|l|}
5 \\
1.5 \\
0.5 \\
2 \\
2.5 \\
1.5
\end{tabular} & $\begin{array}{l}6.8 \\
4.5 \\
4 \cdot 3 \\
6.5 \\
7.5 \\
7.3\end{array}$ & $\begin{array}{l}16 \cdot 5 \\
12 \\
13 \\
15 \\
16 \\
18\end{array}$ & $\begin{array}{l}2 \\
1 \\
0.5 \\
2 \\
2.5 \\
2.5\end{array}$ & $\begin{array}{r}10.4 \\
7.8 \\
9.5 \\
13.9 \\
13.4 \\
12.9\end{array}$ & $\begin{array}{l}20 \\
18 \\
16 \cdot 5 \\
25 \\
24 \\
20 \cdot 5\end{array}$ & $\begin{array}{l}3 \\
2 \\
2 \\
5 \\
3 \cdot 5 \\
5\end{array}$ & $\begin{array}{l}2.9 \\
3.6 \\
6.4 \\
8.6 \\
8.5 \\
9.5\end{array}$ & $\begin{array}{l}11.5 \\
11 \\
14 \\
18.5 \\
21 \\
17\end{array}$ & $\begin{array}{l}0.5 \\
0 \\
1 \\
1 \\
0.5 \\
3\end{array}$ \\
\hline
\end{tabular}

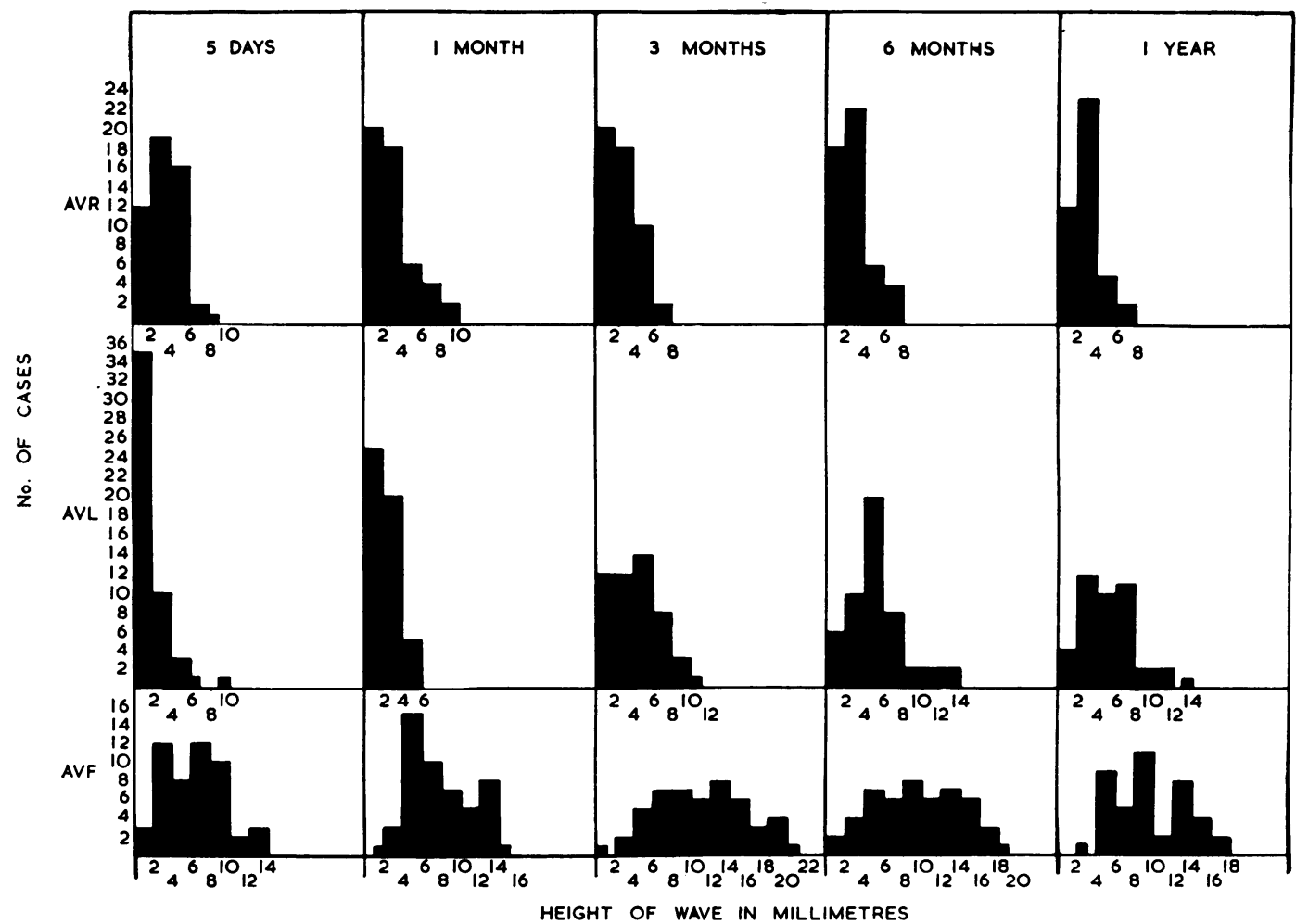

FIG. 2.-Distribution of $R$ wave values in leads AVR, AVL, and AVF. 
were prepared for the $\mathbf{R}$ and $\mathbf{S}$ waves only and were condensed for presentation: these show the distribution of the values more clearly.

\section{RESULTS}

$Q$ Waves 1st Day to 1 Year. Our findings are similar to those of Furman and Halloran (1951) and confirm that deep Q waves in leads II, III, AVF, and V6 are not unusual in the first year of life and gradually become deeper between birth and 1 year (Table I and Fig. 7). Our mean values are lower than Ziegler's (1951) although the maximal and minimal values are similar. In five of our records there was difficulty in determining whether the first downward deflection represented a $\mathbf{Q}$ wave or an $\mathrm{S}$ wave. The records were interpreted by four independent observers before reaching a final opinion.

$R$ Waves 1st Day to 1 Year. At birth the $R$ wave is of low amplitude in leads I and V6 and high in AVR and V3R. During the first year of life it increases strikingly in I and V6 indicating progressive increase in the activity of the left ventricle during this period. There is a decrease in the $R$ wave in AVR and V3R but this is less marked, indicating only a slight decrease in right ventricular activity during the first year of life (Table II and Fig. 1, 2, 3, and 7).

In our series mean values in præcordial leads fell well below Ziegler's figures in the first 3 months of life, e.g. in our series the mean value of R V1 at 5 days was $4.5 \mathrm{~mm}$., whereas in Ziegler's (1951) series between 1 day and 1 week it was $17.0 \mathrm{~mm}$. In our study the maximal value of $R \mathrm{~V} 1$ at 5 days was $12 \mathrm{~mm}$., whereas the maximal value in Ziegler's (1951) series between 1 day and 1 week was

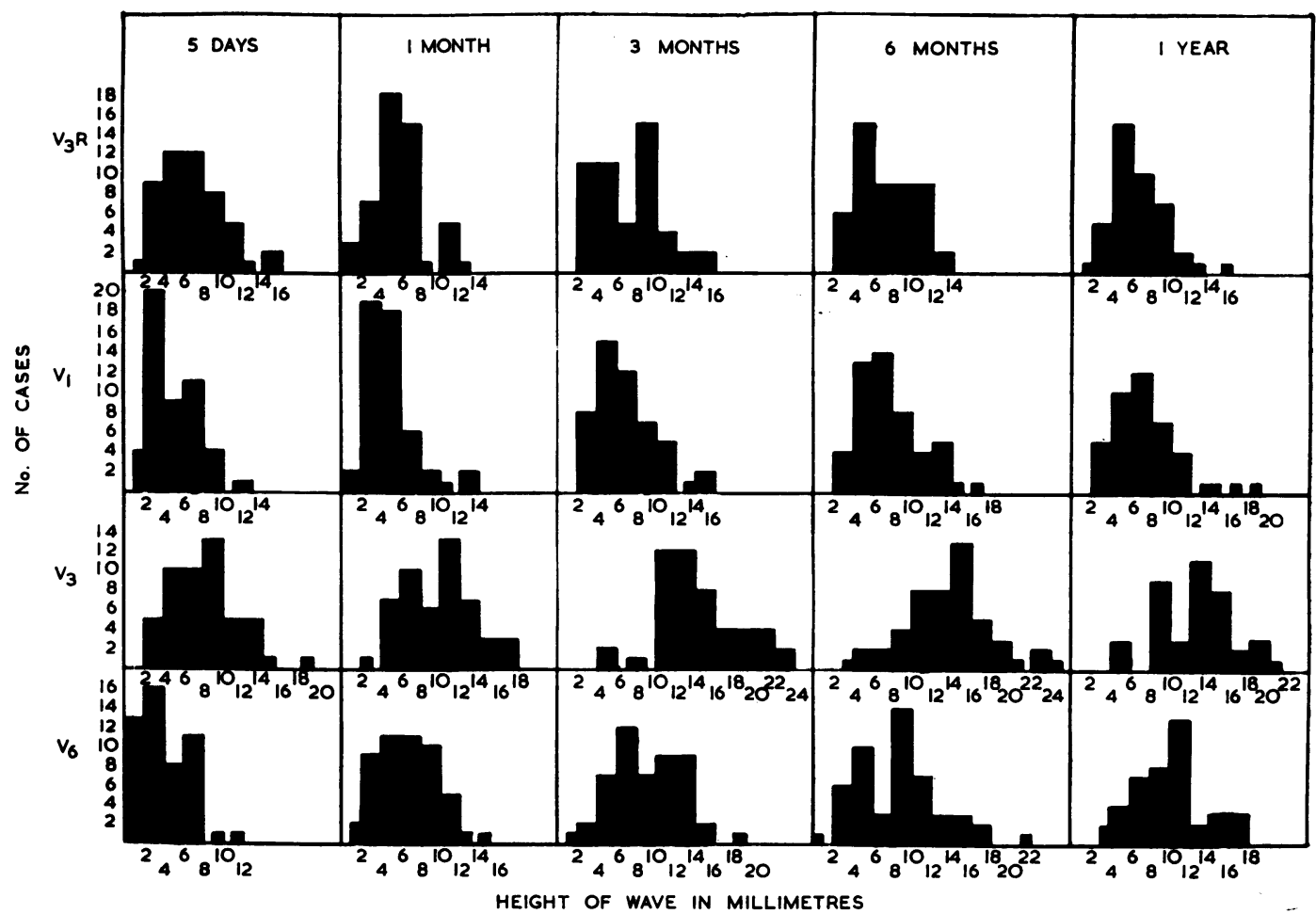

FIG. 3.-Distribution of $R$ wave values in leads V3R, V1, V3, and V6. 


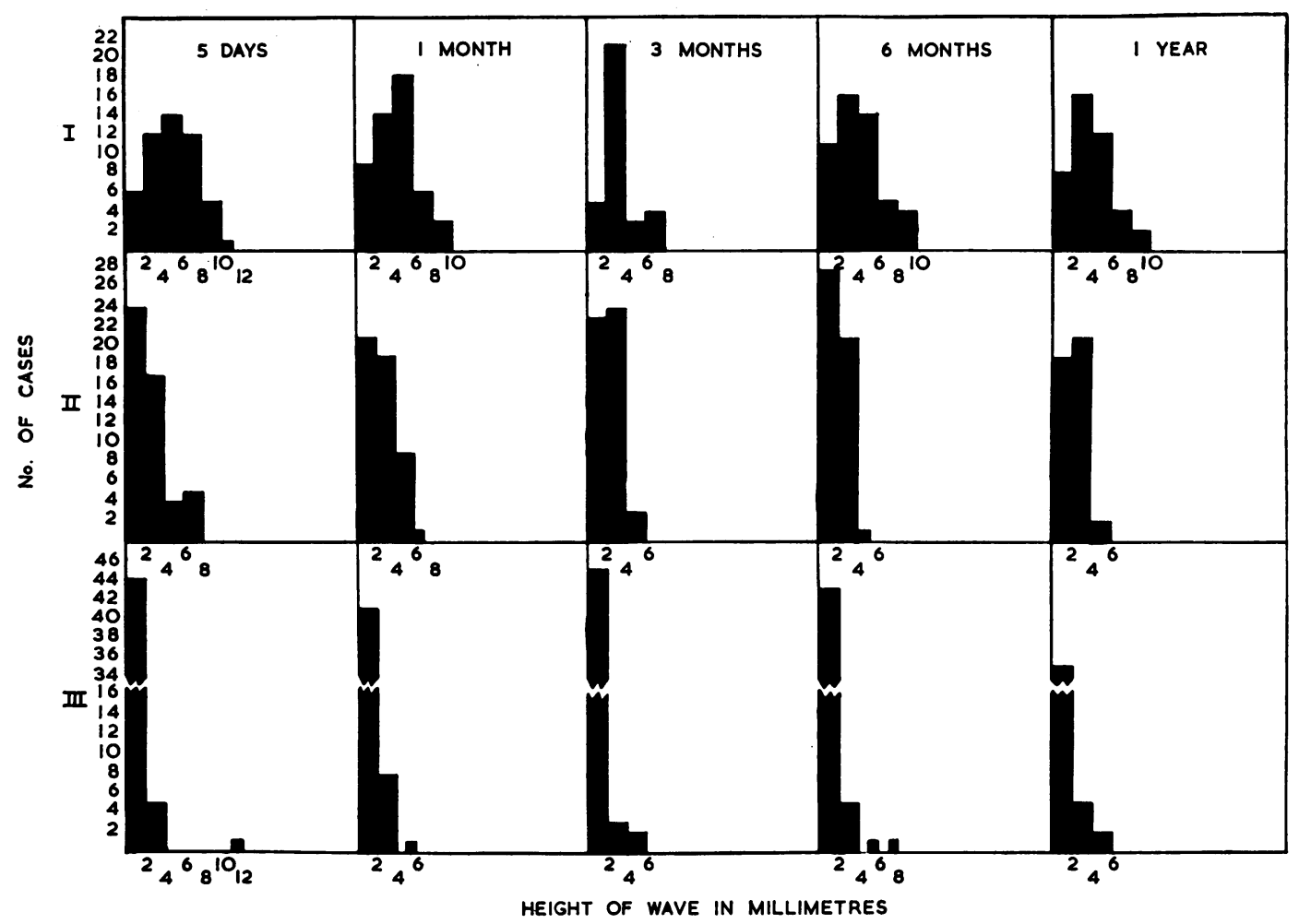

FIG. 4.-Distribution of $\mathrm{S}$ wave values in leads I, II, and III

$29 \mathrm{~mm}$. This disparity was not explained by the slight difference in the ages at which the records were taken in the two series, because as subsequent analysis showed there was little variation in our daily records during the first seven days of life. After the age of 3 months the mean values in Ziegler's (1951) series and ours were closer but the values in our series were always smaller.

It is difficult to compare our findings with those of Furman and Halloran (1951) because of the different selection of age-groups, but we can compare the findings at 1 month in both series. At this age the maximal values were very close but the mean values were higher in Furman and Halloran's series than in ours, e.g. R V1 at the fourth week in Furman and Halloran's series was $7.0 \mathrm{~mm}$. and in our series was $4.3 \mathrm{~mm}$.

$S$ Waves 1st Day to 1 Year. At birth there is a deep S wave in leads I and V6, the S wave being equal to or greater than the $R$. By the age of 1 year both have decreased significantly indicating some decrease in the activity of the right ventricle during the first year of life. The $S$ waves in V3R, V1, and AVR become deeper, indicating increase in left ventricular activity (Table III and Fig. $4,5,6$, and 7).

Mean values in leads I, II, AVL, and V6 were of the same order of magnitude in our series and in Ziegler's (1951) series, Ziegler's figures being slightly higher in most instances. In leads III, AVR, and AVF there were differences of as much as $3 \mathrm{~mm}$. between the mean figures in the two series, Ziegler's again being the higher. The greatest difference in mean values for the two series was seen in leads V1 and V3 at ages up to 1 month, e.g. in this series the mean figure for S V1 was $3.2 \mathrm{~mm}$. at 5 days and $3.6 \mathrm{~mm}$. at $1 \mathrm{month}$, while Ziegler's mean value was $11.1 \mathrm{~mm}$. for ages 1 day to 1 week, and $7.0 \mathrm{~mm}$. for ages 1 week to 1 month. Again this disparity was not explained by the slight difference in the ages when the records were taken. 
TABLE III

S WAVES

\begin{tabular}{|c|c|c|c|c|c|c|c|c|c|c|c|c|c|}
\hline \multirow[b]{2}{*}{$\begin{array}{c}\text { Age } \\
\text { (mth.) }\end{array}$} & \multirow[b]{2}{*}{$\begin{array}{c}\text { Number } \\
\text { of } \\
\text { subjects }\end{array}$} & \multicolumn{3}{|c|}{ I } & \multicolumn{3}{|c|}{ II } & \multicolumn{3}{|c|}{ III } & \multicolumn{3}{|c|}{ AVR } \\
\hline & & mean & $\max$. & $\min$. & mean & $\max$ & $\min$. & mean & $\max$ & $\min$. & mean & $\max$. & $\min$ \\
\hline $\begin{array}{l}1 \text { day } \\
5 \text { days } \\
1 \\
3 \\
6 \\
12\end{array}$ & $\begin{array}{l}20 \\
50 \\
50 \\
50 \\
50 \\
42\end{array}$ & $\begin{array}{l}5.2 \\
4.7 \\
3.9 \\
3.8 \\
3.5 \\
3.5\end{array}$ & $\begin{array}{r}8.5 \\
10 \cdot 5 \\
8.5 \\
6 \\
9.5 \\
9\end{array}$ & $\begin{array}{l}0 \\
0 \\
0 \\
0 \\
0 \\
0\end{array}$ & $\begin{array}{l}1.8 \\
2.2 \\
2.1 \\
1.8 \\
1.3 \\
1.7\end{array}$ & $\begin{array}{l}6 \\
6 \\
6 \\
5 \cdot 5 \\
4 \cdot 5 \\
4 \cdot 5\end{array}$ & $\begin{array}{l}\mathbf{0} \\
\mathbf{0} \\
\mathbf{0} \\
\mathbf{0} \\
\mathbf{0} \\
\mathbf{0}\end{array}$ & $\begin{array}{l}0.3 \\
0.8 \\
0.8 \\
0.6 \\
0.7 \\
0.7\end{array}$ & $\begin{array}{l}2 \cdot 5 \\
3 \\
5 \\
4 \cdot 5 \\
7 \\
5\end{array}$ & $\begin{array}{l}\mathbf{0} \\
\mathbf{0} \\
\mathbf{0} \\
\mathbf{0} \\
\mathbf{0} \\
\mathbf{0}\end{array}$ & $\begin{array}{l}0.8 \\
1.2 \\
3.8 \\
7.4 \\
7.5 \\
7.6\end{array}$ & $\begin{array}{c}7 \\
7 \\
8 \cdot 5 \\
18 \cdot 5 \\
17 \cdot 5 \\
16\end{array}$ & $\begin{array}{l}0 \\
0 \\
0 \\
0 \\
0 \\
0\end{array}$ \\
\hline
\end{tabular}

With isolated exceptions, maximal values in our series for leads I, II, III, AVR, AVL, AVF, and V6 were of the same order as, but slightly smaller than, those in Ziegler's series. In leads V1 and V3, however, at ages during the first 3 months, maximal figures in our series were substantially smaller than in Ziegler's series, e.g. in V1 the maximal figures in our series were $11.5 \mathrm{~mm}$. at 5 days and

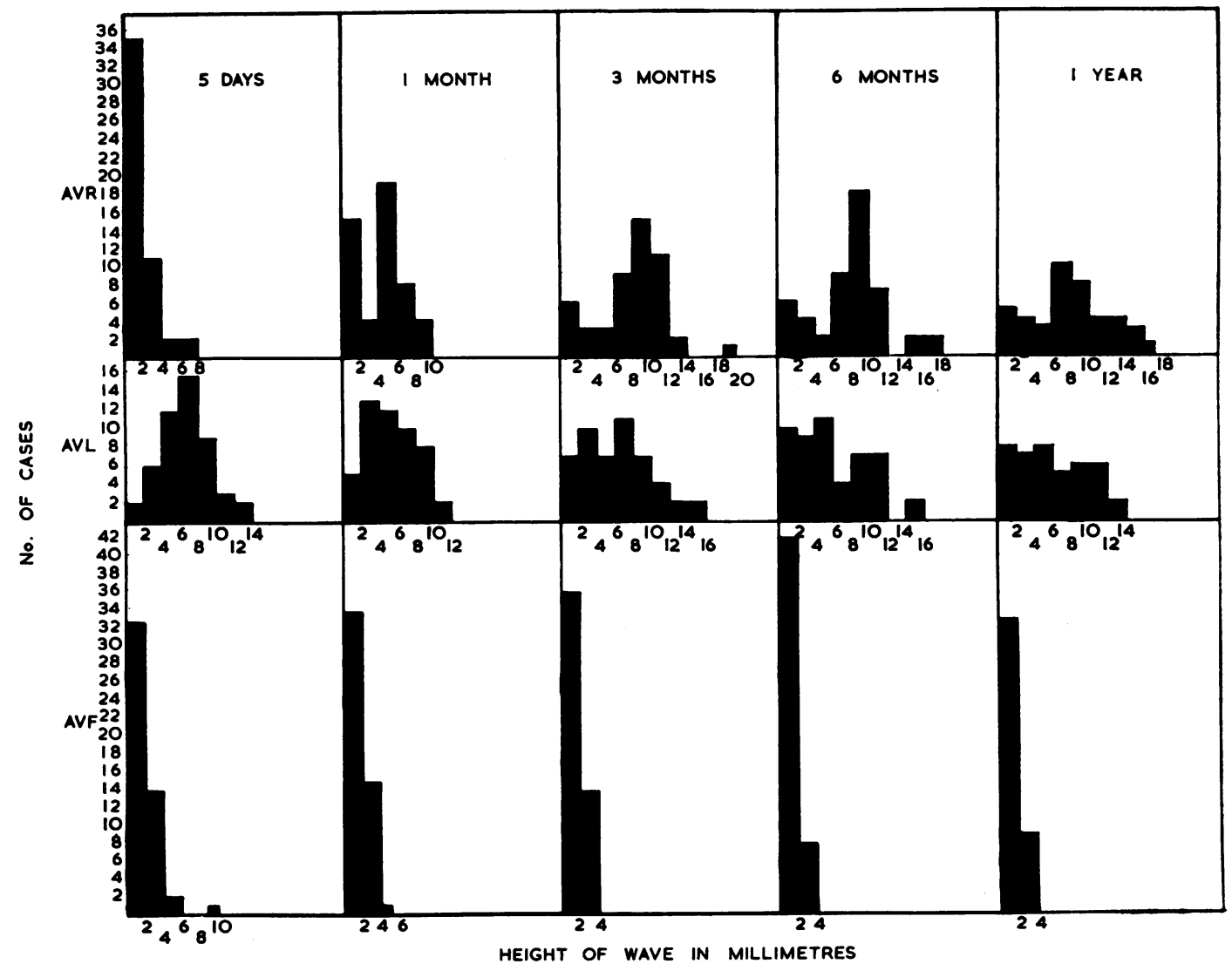

Fig. 5.-Distribution of $S$ wave values in lead AVR, AVL, and AVF. 
TABLE III (continued)

\begin{tabular}{|c|c|c|c|c|c|c|c|c|c|c|c|c|c|c|c|c|c|}
\hline \multicolumn{3}{|c|}{ AVL } & \multicolumn{3}{|c|}{ AVF } & \multicolumn{3}{|c|}{ V3R } & \multicolumn{3}{|c|}{ V1 } & \multicolumn{3}{|c|}{ V3 } & \multicolumn{3}{|c|}{ V6 } \\
\hline mean & $\max$. & $\min$ & mean & $\max$ & $\min$. & mean & $\max$ & $\min$. & mean & $\max$ & $\min$. & mean & $\max$. & $\min$. & mean & $\max$. & $\min$. \\
\hline $\begin{array}{l}7 \cdot 3 \\
6 \cdot 4 \\
5 \\
5 \cdot 9 \\
5 \cdot 4 \\
5 \cdot 5\end{array}$ & $\begin{array}{l}13.5 \\
12.5 \\
11.5 \\
16 \\
15.5 \\
13\end{array}$ & $\begin{array}{l}2 \cdot 5 \\
0 \\
0 \\
0 \\
0 \\
0\end{array}$ & $\begin{array}{l}0.9 \\
1.3 \\
1.2 \\
0.9 \\
0.6 \\
0.9\end{array}$ & \begin{tabular}{|l|}
$5 \cdot 5$ \\
9 \\
4 \\
6 \\
$3 \cdot 5$ \\
$4 \cdot 5$
\end{tabular} & $\begin{array}{l}0 \\
0 \\
0 \\
0 \\
0 \\
0\end{array}$ & $\begin{array}{l}4 \\
4 \cdot 1 \\
3 \cdot 6 \\
4 \cdot 1 \\
4 \cdot 6 \\
4 \cdot 8\end{array}$ & $\begin{array}{l}11.5 \\
10 \\
11.5 \\
11 \\
11.5 \\
10\end{array}$ & $\begin{array}{l}0 \\
0 \\
0 \\
0 \\
0 \\
0\end{array}$ & $\begin{array}{l}2 \cdot 8 \\
3 \cdot 3 \\
3 \cdot 7 \\
4 \cdot 8 \\
5.9 \\
5 \cdot 9\end{array}$ & $\begin{array}{l}11.5 \\
11.5 \\
10.5 \\
13.5 \\
13 \\
19\end{array}$ & $\begin{array}{l}0 \\
0 \\
0 \\
1 \\
0 \\
0\end{array}$ & $\begin{array}{r}13.3 \\
9.9 \\
10.9 \\
12.2 \\
11.5 \\
12.1\end{array}$ & $\begin{array}{l}21 \\
17 \\
19 \\
22 \cdot 5 \\
20 \\
20\end{array}$ & \begin{tabular}{|l|}
$5 \cdot 5$ \\
2 \\
3 \\
2 \\
1 \\
5
\end{tabular} & $\begin{array}{l}2 \cdot 9 \\
3 \cdot 2 \\
3 \cdot 1 \\
2 \cdot 6 \\
2 \\
2\end{array}$ & $\begin{array}{c}6 \\
11 \\
8 \cdot 5 \\
8 \\
6 \\
8 \cdot 5\end{array}$ & $\begin{array}{l}0 \cdot 5 \\
0 \\
0 \\
0 \\
0 \\
0\end{array}$ \\
\hline
\end{tabular}

$10.5 \mathrm{~mm}$. at 1 month, while in Ziegler's series the maximal figures were $25 \mathrm{~mm}$. at ages from 1 day to 1 week, and $17.5 \mathrm{~mm}$. at ages 1 week to 1 month. After the age of 3 months, the maximal figures in the two series approximated much more closely to each other in V1, but in V3 there remained a difference of at least $6 \mathrm{~mm}$., Ziegler's figures remaining larger than those in our series.

Comparing values in our series with those of Furman and Halloran (1951) where age-groups coincided, i.e. at 1 month, the mean values in both series were similar in leads II, III, AVR, AVL, and V6. In leads I, V1, and V3 there was a difference measuring up to $2 \mathrm{~mm}$.; e.g. in our series the

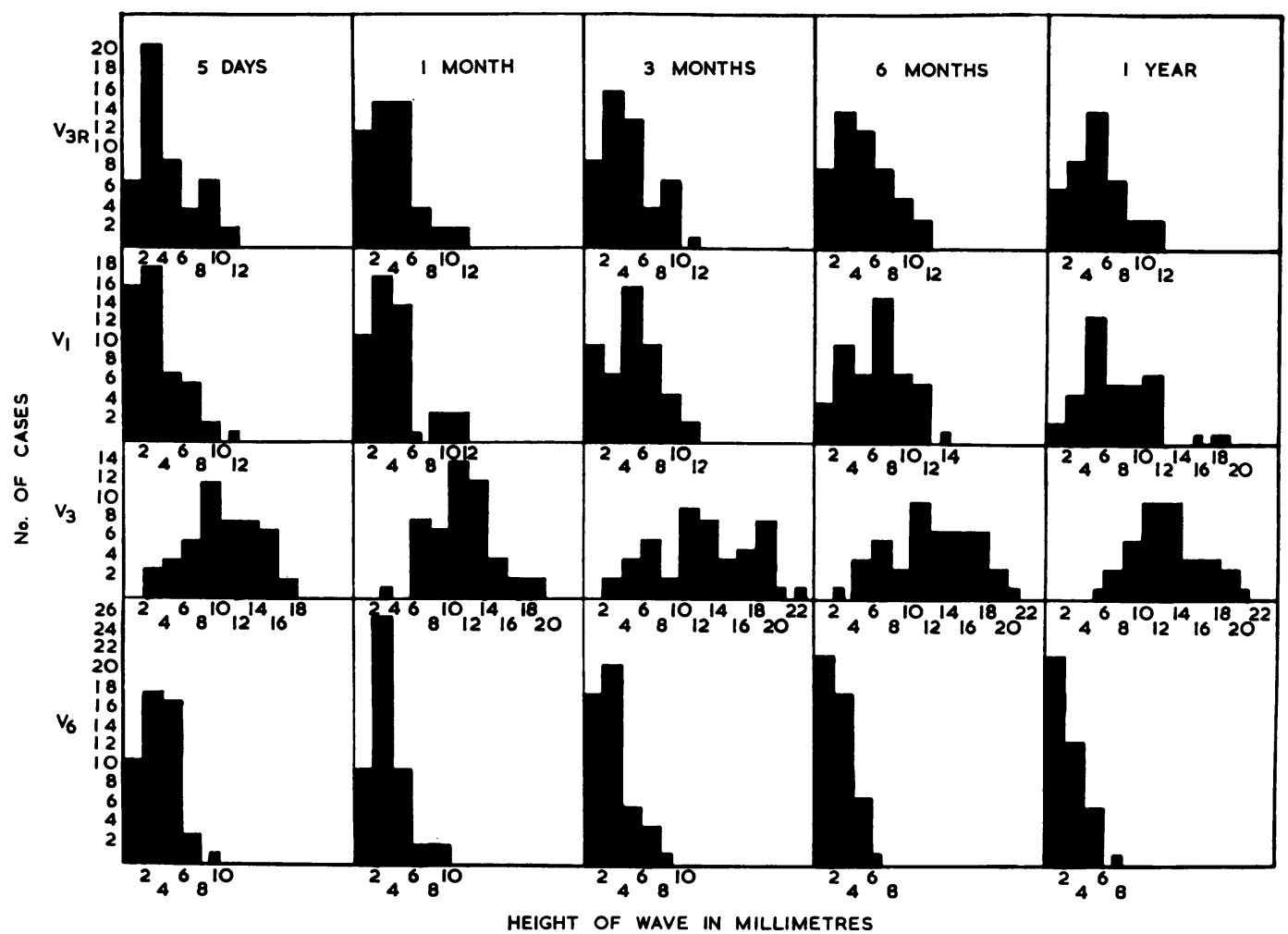

FIG. 6.-Distribution of $S$ wave values in leads V3R, V1, V3, and V6. 
TABLE IV

T WAVES

\begin{tabular}{|c|c|c|c|c|c|c|c|c|c|c|c|c|c|}
\hline \multirow[b]{2}{*}{$\begin{array}{c}\text { Age } \\
\text { (mth.) }\end{array}$} & \multirow[b]{2}{*}{$\begin{array}{l}\text { Number } \\
\text { of } \\
\text { subjects }\end{array}$} & \multicolumn{3}{|c|}{ I } & \multicolumn{3}{|c|}{ II } & \multicolumn{3}{|c|}{ III } & \multicolumn{3}{|c|}{ AVR } \\
\hline & & mean & $\max$ & $\min$. & mean & $\max$ & $\min$. & mean & $\max$ & $\min$ & mean & $\max$ & $\min$. \\
\hline $\begin{array}{l}1 \text { day } \\
5 \text { days } \\
1 \\
3 \\
6 \\
12\end{array}$ & $\begin{array}{l}17 \\
40 \\
40 \\
40 \\
40 \\
25\end{array}$ & $\begin{array}{l}+0 \cdot 3 \\
+1 \\
+1.5 \\
+2.2 \\
+2.2 \\
+2.7\end{array}$ & $\begin{array}{l}+1 \cdot 5 \\
+2.5 \\
+4 \cdot 5 \\
+4 \\
+5 \\
+5.5\end{array}$ & $\begin{array}{l}-3 \\
+0.5 \\
-1 \\
+0.5 \\
+1 \\
+0.5\end{array}$ & $\begin{array}{l}+1 \\
+1.2 \\
+1 \cdot 7 \\
+2 \cdot 7 \\
+2 \cdot 8 \\
+3 \cdot 2\end{array}$ & $\begin{array}{l}+2 \\
+2.5 \\
+3 \\
+4.5 \\
+6 \\
+5.5\end{array}$ & $\begin{array}{l}-0.5 \\
+0.5 \\
+0.5 \\
+1.5 \\
+1 \\
+1.5\end{array}$ & $\begin{array}{l}+0.9 \\
+0.5 \\
+0.7 \\
+0.8 \\
+0.9 \\
+0.6\end{array}$ & $\begin{array}{l}+3 \\
+1 \\
+0 \cdot 5 \\
+1 \cdot 5 \\
+1 \\
+3\end{array}$ & $\begin{array}{l}-0.5 \\
-1 \\
-0.5 \\
-1.5 \\
-1 \\
-1.5\end{array}$ & $\begin{array}{l}-0.7 \\
-1.1 \\
-1.7 \\
-2.4 \\
-2.6 \\
-3\end{array}$ & $\begin{array}{l}+3 \\
-0.5 \\
-0.5 \\
-1.5 \\
-1 \\
-1\end{array}$ & $\begin{array}{l}-2 \\
-2 \\
-4 \\
-4 \cdot 5 \\
-5 \\
-4 \cdot 5\end{array}$ \\
\hline
\end{tabular}

mean value was $3.6 \mathrm{~mm}$. in V1 at 1 month and the corresponding figure in Furman and Halloran's series was $4.9 \mathrm{~mm}$. Maximal values in the two series at 1 month were closely similar, except in leads AVF and V3 where there were differences of 3 and $5 \mathrm{~mm}$. respectively, Furman and Halloran's figures being the smaller in both instances.

$T$ Waves 1st Day to 1 Year. In all leads the trend was towards an increase in height or depth of the wave with increasing age (Table IV). Most T waves in all leads were either positive or negative,

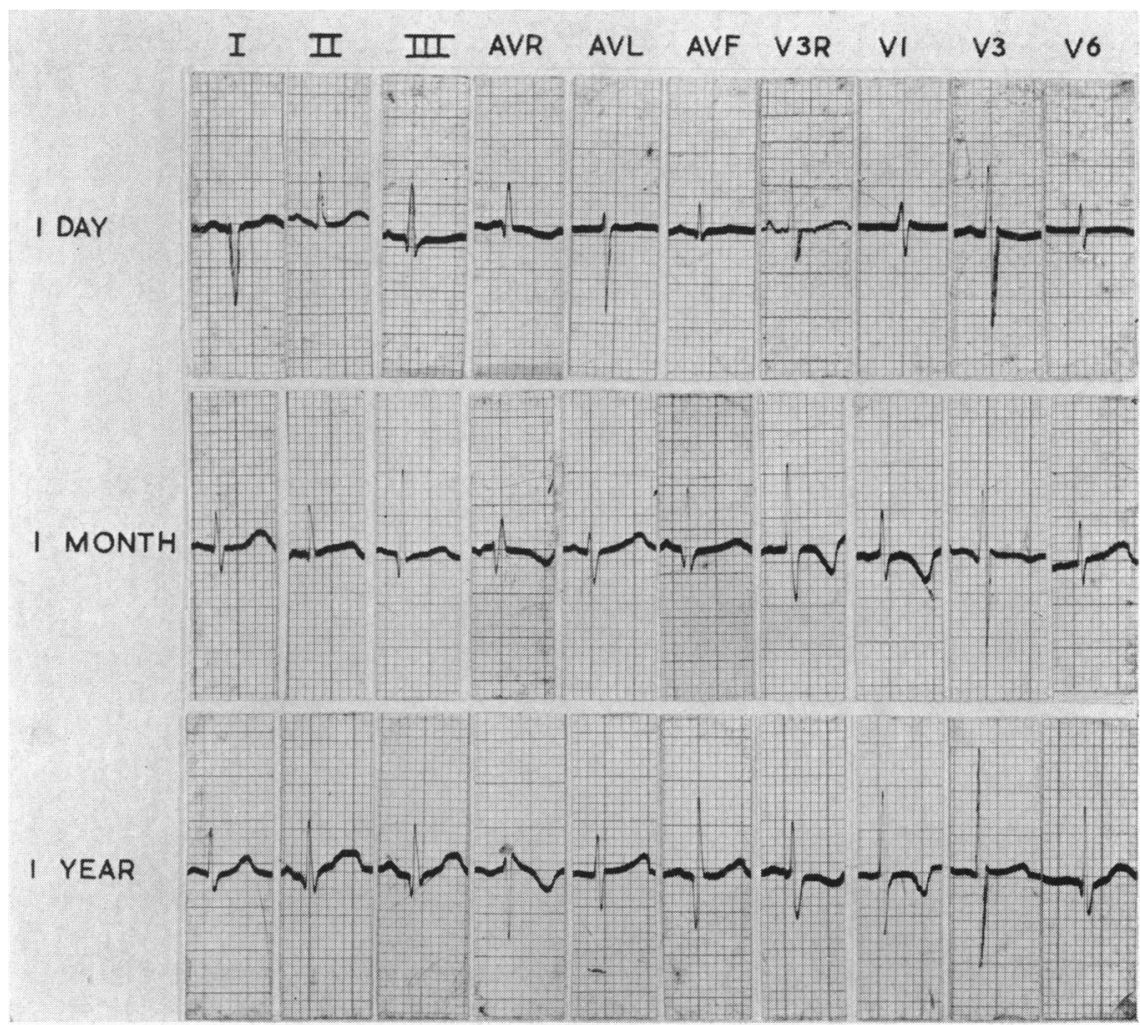

FIG. 7.-Typical electrocardiograms at 1 day, 1 month, and 1 year. 
Table IV (continued)

\begin{tabular}{|c|c|c|c|c|c|c|c|c|c|c|c|c|c|c|c|c|c|}
\hline \multicolumn{3}{|c|}{ AVL } & \multicolumn{3}{|c|}{ AVF } & \multicolumn{3}{|c|}{ V3R } & \multicolumn{3}{|c|}{ V1 } & \multicolumn{3}{|c|}{ V3 } & \multicolumn{3}{|c|}{ V6 } \\
\hline mean & $\max$ & $\min$. & mean & $\max$ & $\min$ & mean & $\max$ & $\min$. & mean & $\max$ & $\min$ & mean & $\max$ & $\min$. & mean & $\max$ & $\min$. \\
\hline $\begin{array}{l}-0.3 \\
+0.5 \\
+0.6 \\
+1.2 \\
+0.9 \\
+1.1\end{array}$ & $\begin{array}{l}+1 \cdot 5 \\
+2 \\
+3 \cdot 5 \\
+3 \\
+2 \cdot 5 \\
+3\end{array}$ & $\begin{array}{l}-2.5 \\
-2 \\
-1.5 \\
-1 \\
-1 \\
-1\end{array}$ & $\begin{array}{l}+1.2 \\
+1 \\
+1.3 \\
+1.6 \\
+1.8 \\
+1.7\end{array}$ & $\begin{array}{l}+2 \cdot 5 \\
+2 \\
+4 \\
+4 \\
+4 \\
+4\end{array}$ & $\begin{array}{l}-0.5 \\
+0.5 \\
+0.5 \\
+0.5 \\
+0.5 \\
+0.5\end{array}$ & $\begin{array}{l}+0.6 \\
-0.7 \\
-1.3 \\
-1.9 \\
-2 \\
-2.2\end{array}$ & $\begin{array}{l}+6 \\
-0.5 \\
-0.5 \\
-0.5 \\
-0.5 \\
-1\end{array}$ & $\begin{array}{l}-2 \\
-2 \cdot 5 \\
-2 \\
-4 \\
-5 \\
-3\end{array}$ & $\begin{array}{l}+0.3 \\
-0.8 \\
-1.2 \\
-2 \\
-2.3 \\
-2.3\end{array}$ & $\begin{array}{l}+4.5 \\
-0.5 \\
-0.5 \\
-0.5 \\
-0.5 \\
-0.5\end{array}$ & $\begin{array}{l}-1 \cdot 5 \\
-2 \\
-2 \\
-4 \\
-5 \cdot 5 \\
-5\end{array}$ & $\begin{array}{c}0 \\
-0.6 \\
-0.3 \\
+0.2 \\
+0.2 \\
-0.2\end{array}$ & $\begin{array}{l}+2 \cdot 5 \\
+1 \\
+1 \cdot 5 \\
+3 \\
+3 \\
+3.5\end{array}$ & $\begin{array}{l}-1.5 \\
-0.5 \\
-2 \\
-3 \\
-3 \\
-2.5\end{array}$ & $\begin{array}{r}+0.7 \\
+1.9 \\
+1.4 \\
+2 \\
+1.9 \\
+2.6\end{array}$ & $\begin{array}{l}+2 \cdot 5 \\
+3 \\
+3 \\
+4 \\
+4 \\
+4 \cdot 5\end{array}$ & $\begin{array}{l}-1 \\
+0.5 \\
+0.5 \\
+0.5 \\
+0.5 \\
+1.5\end{array}$ \\
\hline
\end{tabular}

but significant numbers of biphasic waves occurred in leads V3R, V1, and V3 at 5 days and 1 month. The number of biphasic waves in these leads decreased as age increased, and in lead V1 there were no biphasic waves by the age of 1 year. Biphasic T waves occurred only rarely in leads III, AVF, AVL, and V6, and no biphasic waves were found in leads I, II, and AVR.

In all the records discussed, only six $\mathrm{T}$ waves were found to be isoelectric. Four of these were found in lead AVL at different ages, and the remaining two isoelectric waves occurred in leads V3R and V3, both on the first day.

Daily Electrocardiograms in First 7 Days of Life. The only significant changes during the first 7 days of life were in the T waves in leads V3R and V1. In the first 24 hours of life almost half the T waves were positive in these leads but during the succeeding days they became negative and by the fifth day all the $T$ waves were negative. Our findings thus agree with those of Richman and Master (1951) and Datey and Bharucha (1960).

There was no significant change in the $\mathrm{Q}, \mathrm{R}$, and $\mathrm{S}$ waves during the first week of life.

\section{SUMMARY AND CONCLUSIONS}

A 10-lead electrocardiogram was recorded in 50 normal infants, recordings being made at 5 days, 1 month, 3 months, 6 months, and 1 year. In 20 of these infants recordings were made daily for 7 days commencing within the first 24 hours of life. The results have been recorded in Tables giving the maximum, minimum, and mean values of the $\mathrm{Q}, \mathrm{R}, \mathrm{S}$, and $\mathrm{T}$ waves. Histograms have been prepared to show the distribution of the values of the $R$ and $S$ waves during the period studied.

The recordings show that there is a gradual increase in the activity of the left ventricle between birth and 1 year. This is shown mainly by an increase in the height of the $R$ wave in lead V6, although there is also some deepening of the $\mathrm{S}$ wave in lead V1. There is a decrease in right ventricular activity during the first year of life but this is less impressive than the increase in left ventricular activity.

We confirm previous observations that deep Q waves are not unusual in leads III, AVF, and V6 in the first year of life and that positive T waves are commonly found in leads V3R and V1 on the first day of life but by the fifth day of life they have all become negative.

We are greatly indebted to our Senior Cardiographer, Mr. Norman Clarke, for his help in recording the electrocardiograms. Our thanks are also due to Mr. K. Tweedie for his statistical advice, to Mr. C. Fitzsimmons for the illustrations, and to Miss S. Johnson and Miss M. Platt for secretarial help. We wish to thank Professor J. D. Hay for his help and criticism. 


\section{REFERENCES}

Bengtsson, E. (1956). The terminal complex of electrocardiograms from normal children in extremity, CR, V and CF leads, and a comparison with adults. Acta med. scand., 154, 11.

British Cardiac Society (1949). Multiple unipolar leads: report. Brit. Heart J., 11, 103.

Datey, K. K., and Bharucha, P. E. (1960). Electrocardiographic changes in the first week of life. Brit. Heart J., 22, 175.

Furman, R. A. and Halloran, W. R. (1951). The electrocardiogram in the first two months of life. J. Pediat., 39, 307.

Gros, G., Gordon, A., and Miller, R. (1951). Electrocardiographic patterns of normal children from birth to 5 years of age. Pediatrics, $8,349$.

Michaëlsson, M. (1959). Electrocardiographic studies in the healthy newborn. Acta paediat. (Uppsala), 48, Suppl. 117, p. 108.

Richman, B., and Master, A. M. (1951). The unipolar chest and extremity lead electrocardiogram in children (newborn to 10 years old). Amer. Heart J., 41, 687.

Sodi-Pallares, D., Portillo, B., Cisneros, F., De la Cruz, M. V., and Acosta, A. R. (1958). Electrocardiography in infants and children. Pediat. Clin. N. Amer., 5, 871.

Ziegler, R. F. (1951). Electrocardiographic Studies in Normal Infants and Children. Thomas, Springfield, Illinois. 